\title{
Hedge Fund Incentives, Management Commitment and Survivorship
}

\author{
Judy Qiu ${ }^{1}$ \\ Leilei Tang ${ }^{2}$ \\ Ingo Walter ${ }^{3}$
}

\begin{abstract}
Studies investigating the relation between managerial ownership and hedge fund survivorship risk find mixed evidence because these studies fail to control for potential endogeneity of management commitment decision. We document that decisions on management ownership are purposely self-selected. Such decisions are most likely motivated by unique incentive mechanisms imbedded in hedge funds. By accounting for unobserved fund manager motivations that affect both ownership decisions, we find no association between the mortality risk of hedge funds and managerial ownership, which suggests that the conventional argument that having management commitment can reduce survival risk (and therefore align the interests between managers and investors) is significantly overstated. These results are robust to using alternative ownership measures and controlling for different samples.
\end{abstract}

Key words: Hedge fund incentive; Endogeneity; Management ownership; Survivorship risk.

JEL: C34, G23, G32

JEL: C34, G23, G32

\footnotetext{
${ }^{1}$ Judy Qiu: Business School, University of Western Australia. 35 Stirling Hwy, Crawley, WA 6009, Australia. Email: judy.qiu@uwa.edu.au

${ }^{2}$ Leilei Tang: Business School, University of Strathclyde. 199 Cathedral Street, Glasgow, G4 0QU, UK. Email: leilei.tang@strath.ac.uk

${ }^{3}$ Ingo Walter: Stern Business School, New York University. 44 West 4th Street, New York, NY 10012, USA. Email: iwalter@stern.nyu.edu
} 


\section{Introduction}

Hedge funds have accumulated a significant market share among qualified individual and institutional investors despite difficult conditions. Nevertheless, Brown et al. (1999), Fung and Hsieh (2000), and Getmansky et al. (2004a) have shown that the hedge fund industry is characterized by a high attrition rate. Short operating lifetimes and the collapse of many high profile funds, such as Long-term Capital Management (LTCM), Peloton Capital, and Tiger Management Corp. (Tiger Fund), have attracted the attention of regulators, investors and academics to survivorship risk in the hedge fund industry. The impact of hedge fund failures on financial stability and how to align fund managers' interests with investors have caused significant policy concerns (Brown et al. 2001; Liang and Park 2010). One concern is governance on the part of hedge fund managers, who are responsible for investment decisions and operations. The US Security and Exchange Commission (SEC) has moved toward regulating hedge funds since 2004, and took a further step under the 2010 Dodd-Frank Act to pursue enforcement actions on governance issues such as remuneration, incentive alignment and public disclosure of investment strategies. In Europe, regulatory changes have also centred on the EU's Alternative Investment Fund Managers Directive (AIFMD). At the same time, the financial press suggests that fund managers should taste their own cooking and criticise the world's largest asset managers including BlackRock with the lowest levels of portfolio manager investment in their funds and the second largest Vanguard with no managerial investment. This paper seeks to contribute to this debate and shed light on empirical links between managerial ownership and hedge fund survivorship risk. In addition, since institutional investors wish to invest in hedge funds on a long-term basis (Casey, Quirk, Acito and the Bank of New York, 2004), it is also interesting to conduct this survival analysis.

Hedge fund managers display distinctive features that separate them from mutual fund managers and traditional corporate executives. Hedge fund managers focus on absolute returns 
and often employ complex financial instruments, intricate trading strategies, and high leverage. Hedge funds also have an unique organizational structure. Compared with managers of public companies, hedge fund managers have near complete control over the structure and operation with fewer methods of discipline, such as stringent board oversight. This may allow fund managers to impose significant agency costs on investors in the form of fraud, performance manipulation, and misaligned compensation incentives (Shadab, 2013, p.149). Ways to potentially align managers' interests with those of fund investors include incentive-based contracts, managerial ownership, dismissal of underperformers, replacement of the management team, and government regulation (Gervais et al., 2005).

In the corporate finance literature, management ownership is one of the mechanisms by which shareholder-compatible incentives are created in order to mitigate the agency problem. In terms of the broader literature on corporate governance relating to ownership structure, Gillan (2006) provides a review on wide range of related issues. The form of managerial ownership $^{4}$ considered in this study is an alternative mechanism to align incentives for value maximization in a manner that is not the result of the contract between hedge fund managers and fund investors. The hedge fund industry differs radically from traditionalcorporations in that managers charge fees which account for the bulk of their income, as opposed to ownership related awards. A distinctive feature of hedge funds is that managers typically levy an incentive fee of 5-25\% of fund profits on top of an administrative fee based on assets under management (AUM), typically about $2 \%$, the so-called "two and twenty" structure. Incentive fees may include a high water mark (HWM) provision, in which incentive fees can be collected only when returns exceed the fund's previous high. How do managerial stakes in their funds come about?

${ }^{4}$ We use the terms management participation, managerial ownership, and personal capital interchangeably in this paper. 
The link between managerial ownership and hedge fund survivorship risk has not been extensively addressed in the literature, and the results of empirical research in support of hedge fund managers' ownership are mixed. Baquero et al. (2005) and Aragon and Nanda (2011) $\underline{\text { suggest that the probability of survivorship risk for funds with high water mark is negatively }}$ associated with fund managers' personal capital invested. In terms of the literature on aligning the interests of the fund manager with those of investors, Agarwal et al. (2009) develop various $\underline{\text { managerial incentive measures and find managerial ownership is positively associated with }}$ $\underline{\text { higher future returns. Lan et al. (2013) demonstrate that managerial ownership can affect hedge }}$ fund managers' risk taking behavior in that higher ownership leading to higher liquidation risk. Boyson (2010), Liang and Park (2010), and Cumming et al. (2015) show that personal capital has no statistically significant impact on fund survivorship.

While these papers advance our understanding of the effects of managerial ownership, a $\underline{\text { limitation of existing empirical studies is that they implicitly assume managerial ownership is }}$ an exogenous (i.e., random) decision. This assumption calls into question the inferences derived from these research. Unlike the traditional corporate governance incentive mechanism, however, managerial ownership in the hedge fund industry is not the result of ex post performance rewards, but rather an ex ante self-selected decision. Hedge fund managers can choose to invest their personal capital in their own funds in order to raise capital and anticipate $\underline{\text { receiving both asymmetric performance-based direct incentive as well as even higher indirect }}$ incentive fees. Lim et al. (2016) suggest the existence of indirect incentives which are 1.4 times larger than direct incentives from incentive fees and managers' personal stakes in the fund. $\underline{\text { How do managerial stakes in their funds come about? }}$

First, fund managers can also use their personal investment as a signal to attract fund inflows and discourage redemptions in order to mechanically increase management fees with few economies of scale. The literature on signaling through retention starts with the seminal 
work by Leland and Pyle (1977). The idea in their paper has been extended in several related contexts. In money management, Gompers and Lerner (1999) and Huberman and Kandel (1993) show that fund managers pick riskier investment strategies in order to signal their ability to gather information that enables them to control and profit from this risk; Das and Sundaram (2002) study the joint role of performance-based compensation as an incentive and a signaling device. It is generally accepted that skill and performance are associated with managers' choices of retention, compensation, and risk. In the hedge-fund industry, it has often been acknowledged that managers may try to signal their ability by investing their own money in the fund they manage. But sending a costly signal may be profitable only if investors are willing to pay more for the service of the high quality managers. However, if the signal is not too costly for the low ability manager to imitate, the signal may not be informative and then investors can not differentiate their choices on the basis of the signal. Such difficulty in providing a credible signal of quality in the financial market is emphasized by Vanasco (2014) who assumes that, in markets for asset backed securities, investors are unable to fully screen the quality of the different assets (a no-transparency assumption). These observations are in line with the theoretical analysis documented by Foster and Young (2010), in which "managers with no superior information or skill can capture a portion of the fees intended to reward those $\underline{\text { managers who do have such information and skill. In effect, managers who have no ability can }}$ $\underline{\text { ride on the coat-tails of managers who do." As such, a tentative hypothesis would therefore be }}$ that a management participation decision itself may be non-informative for investors. In this case the co-investment decision is made regardless of the expected future performance of the fund when managers can earn $2 \%$ on hedge fund AUM with certainty, dependent solely on AUM size, which in turn is likely to be backstopped by redemption limits. On average, $\underline{\text { management fees account for a significant share of industry-wide manager compensation than }}$ performance fees (Shadab, 2013, p.169). In a recent study, Lim et al. (2016) estimate that "on 
average managers receive 16 cents in direct pay and at least 23 cents in indirect pay for each incremental dollar earned for fund investors. ... and indirect incentives are even larger for young funds (p.873)". This finding shows that hedge fund managers could be motivated to have skin in the game not by interest alignment but by higher expected future fee income. A modest co-investment could pay off handsomely for managers if it causes AUM to grow significantly larger than without co-investment, regardless of hedge fund performance, indicating that the cost of a co-investment signal can be low for poor quality managers to $\underline{\text { imitate. As a result, high management fees become a big profit centre (Yin 2016) which distorts }}$ fund manager incentives. Fee-based incentive misalignment in the hedge fund industry is well documented; for example "zombie funds", such as the infamous collapse of Amaranth whose manager Brian Hunter lost $\$ 7$ billion for Amaranth, but still collected more than $\$ 100$ million in compensation after its demise. Later he became an adviser to a different hedge fund, Peak Ridge Capital..$^{5}$ Ozik and Sadka (2015) show that fund managers with skin in the game tend to profit from inside information about fund flows and they have the incentive to withdraw personal capital stakes precede investors. In these circumstances, if hedge fund managers purposely self-select to participate and unobserved factors are not controlled simply by treating personal capital as an exogenous covariate as in prior literature, the effect of personal capital on survival risk cannot be interpreted.

Second, in general there is no requirement that fund managers must have their personal wealth invested in the funds they manage. Co-investment decisions can be motivated by the prospect of financial gain. The common view is that the fund manager may be better informed $\underline{\text { than fund investors regarding fund performance, and therefore has an incentive to participate }}$

${ }^{5}$ Celarier presents another example in her article, stating "One hedge fund honcho whose multibillion-dollar fund shut down in 2008 says that he got the biggest payday of his career that year, thanks to the management fees collected before the fund's demise". Survival of the Fattest. Institutional Investor (March 29, 2012). http://www.institutionalinvestor.com/Article/3001820/Research/4368/Overview.html\#.V6hYsqI5TN4 
in excess gains on fund returns. But equity-based rewards and equity options are usually the ownership result of ex post performance. ${ }^{6}$ In contrast, the co-investment decision by hedge fund managers tends to be ex ante and motivated for marketing purposes. Hedge fund managers may also be motivated to use a co-investment decision for tax purposes in which they structure the ownership of their funds in conjunction with retirement vehicles to tax-shelter capital appreciation.

A possible justification for hedge fund managers not to invest in their own fund is diversification. Hedge fund managers are presumed to be normally risk-averse when it comes to their total net worth. Their risk preference may differ widely from institutional investor clients. The latter are typically tax-exempt and long-term in their investment horizon. Individuals tend to be fully taxed and have far shorter investment horizons. These differences, along with a desire for capital protection, may cause hedge fund managers to limit the amount of their net worth invested in their funds.

$\underline{\text { As such, hedge fund managers can self-select, making capital contribution decisions based }}$ on unobservable personal motivations and financial gain calculations, causing the participation decision not to be random, but rather purposely and endogenously chosen. If unobservable attributes affect both the management participation decision process and the fund survivorship process, then simply regressing fund survivorship on a management participation variable may not accurately capture the impact of management participation on hedge fund survivorship risk unless unobserved attributes are incorporated in the model.

${ }^{6}$ We acknowledge that it is difficult for hedge funds to raise capital from institutional investors during the incubation period, forcing managers to use internal capital to generate a track record. This shows that such a coinvestment decision is not for aligning interests between fund managers and investors but because of the difficulty of raising capital. Some hedge funds have compulsory co-investment requirements for their managers. Those managers may instead regard such investments as being a cost of employment. 
The view that managerial ownership ${ }^{7}$ aligns the incentives of management and investors pervades the general corporate governance literatme, and this carries over to the asset management industry (see, for example, Khorana et al. 2007). Investors tend to have confidence in fund managers with skin in the game and this has become a guiding principle for investors' investment decisions. However, the link between managerial ownership and hedge fund survivorship risk has not been extensively addressed in the literature, and the results of empirical research in support of hedge fund managers' ownership are mixed. Baquero et al. (2005) and Aragon and Nanda (2011) suggest that the probability of survivorship risk for funds with high water mark is negatively associated with fund managers' personal capital invested. In terms of the literature on aligning the interests of the fund manager with those of investors, Agarwal et al. (2009) develop various managerial incentive measures and find managerial ownership is positively associated with higher future returns. Lan et al. (2013) demonstrate that managerial ownership can affect hedge fund managers' risk taking behavior in that higher ownership leading to higher liquidation risk. Boyson (2010), Liang and Park (2010), and Cumming et al. (2015) show that personal capital has no statistically significant impact on fund survivorship.

The remainder of the paper proceeds as follows. Section 2 discusses the research design and models employed. reviews the related literature and develops the endogeneity arguments. Section 3 discusses the research design and models employed. The description of our data on hedge fund characteristics is presented in section $\underline{3}-4$. The empirical results are presented in section $5 \underline{4}$. Section $6 \underline{5}$ concludes.

\subsection{Self-selection of management participation and fund survivorship}

The standard model of management participation includes a fund manager whose motivation and ability are private information. The principal agent model may be used to describe the 
willingness of a manager (agent) to signal his/her ability to the investors (principal) by sending

We conduct a Monte Carlo numerical experiment to investigate the impact of ignoring the potential endogeneity of management participation on survivorship risk. The data generating process for the simulation experiment allows us to show how biased the estimator is when one fits a model to data that are truly generated by the existence of endogeneity. In essence, the managerial participation decision is designed to be endogenous but has no statistical relationship with the fund survivorship risk process. This design can enable us to assess the importance of incorporating endogeneity for management participation decisions, an issue that has not yet been explored. The experimental setting and numerical results are presented in Appendix A. The simulation results show that the simulated estimator bias increases in absolute value as the correlation between management participation and survival processes increases, suggesting the causal effect of management participation decision on survival risk cannot be interpreted. The bias disappears as the correlation approaches zero. Also, the simulation results show that increasing the number of observations cannot make the bias disappear. Therefore, the potential endogenous choice of the managerial ownership decision for hedge funds needs to be accounted for. We propose a method for doing so in the following sub-section.

Empirical corporate finance research has shown that managerial ownership reduces agency conflicts between investors and corporate managers. The conventional wisdom that coinvestment aligns the interests of hedge fund managers and their investors has developed from the standard corporate governance model in which managerial ownership takes the form of equities purchases by managers, equity based compensation and/or equity option awards as incentives for better corporate performance. In the stylized model developed by Jensen and Meckling (1976), the prediction is that the level of managerial ownership is negatively associated with agency costs. Although later research suggests that the relationship between the extent of managerial ownership and agency costs is non monotonic (McConnell and 
Servaes, 1990; Morck et al., 1988), it is generally recognized that managerial ownership can

In the corporate finance literature, management ownership is one of the mechanisms by

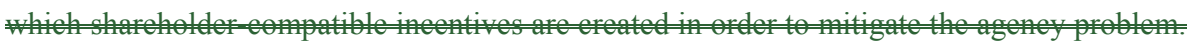
In o th to to

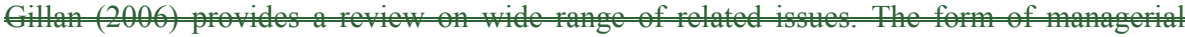
ownership considered in this study is an alternative mechanism to align incentives for value maximization in a manner that is not the result of the contract between hedge fund managers

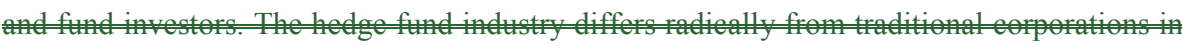
tha

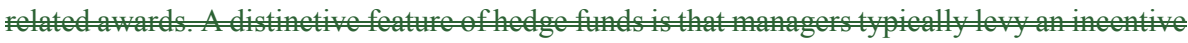
fee 0 f 5-25\% of fund profits on top of an administrative fee based on assets under management (AUM), typically about 2\%, the so-ealled "two and twenty" structure. Incentive fees may

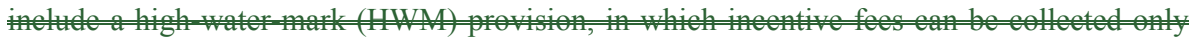

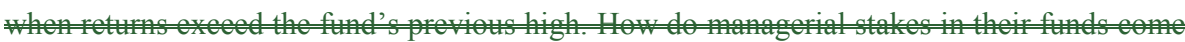
about?

First, hedge fund managers may also use their personal investment as a signal to attract fund inflows and discourage redemptions. In this case the co investment decision is made regardless of the expected future performance of the fund when managers can earn $2 \%$ on hedge fund AUM with certainty, dependent solely on AUM size, which in turn is likely to be backstopped by redemption limits. On average, management fees account for a significant share of industry wide manager compensation than performance fees (Shadab, 2013, p.169). In a recent study, Lim et al. (2016) estimate that "on average managers receive 16 cents in direct pay and at least 23 cents in indirect pay for each incremental dollar earned for fund investors. ... and indirect incentives are even larger for young funds (p.873)". This finding shows that hedge fund managers could be motivated to have skin in the game not by interest 
alignment but by higher expected future fee income. A modest co investment could pay off handsomely for managers if it causes AUM to grow significantly larger than without coinvestment, regardless of hedge fund performance, indicating that the cost of a co-investment signal can be low for poor quality managers to imitate. As a result, high management fees become a big profit centre (Yin 2016) which distorts fund manager incentives.

Second, in general there is no requirement that fund managers must have their personal wealth invested in the funds they manage. Co investment decisions can be motivated by the prospect of financial gain. The common view is that the fund manager may be better informed than fund investors regarding fund performance, and therefore has an incentive to participate in excess gains on fund returns. But equity-based rewards and equity options are usually the 
ownership result of ex post performance. ${ }^{9}$ In contrast, the co investment decision by hedge fund managers tends to be ex ante and motivated for marketing purposes. Hedge fund managers may also be motivated to use a co-investment decision for tax purposes in which they structure the ownership of their funds in conjunction with retirement vehicles to tax-shelter eapital appreciation.

A possible justification for hedge fund managers not to invest in their own fund is diversification. Hedge fund managers are presumed to be normally risk averse when it comes to their total net worth. Their risk preference may differ widely from institutional investor clients. The latter are typically tax-exempt and long-term in their investment horizon. Individuals tend to be fully taxed and have far shorter investment horizons. These differences, along with a desire for capital protection, may cause hedge fund managers to limit the amount of their net worth invested in their funds.

As such, hedge fund managers can self-select, making capital contribution decisions based on unobservable personal motivations and financial gain calculations, causing the participation decision not to be random, but rather purposely and endogenously chosen. If unobservable attributes affect both the management participation decision process and the fund survivorship process, then-simply regressing fund survivorship on a management participation variable may not accurately capture the impact of management participation on hedge fund survivorship risk unless unobserved attributes are incorporated in the model. We conduct a Monte Carlo numerical experiment to investigate the impact of ignoring the potential endegeneity of management participation on-survivorship risk. The data generating process for the simulation experiment allows us to show how biased the estimator is when one fits a model to data that are truly generated by the existence of endogeneity. In essence, the managerial participation decision is designed to be endogenous but has no statistical relationship with the fund survivorship risk process. This design can enable us to assess the impertance of incerperating 
endogeneity for management participation decisions, an issue that has not yet been explored. The experimental setting and numerieal results are presented in Appendix $A$. The simulation results show that the simulated estimator bias increases in absolute value as the correlation between management participation and survival processes increases, suggesting the causal effect of management participation decision on survival risk cannot be interpreted. The bias disappears as the correlation appreaches zero. Also, the simulation results show that increasing the number of observations cannot make the bias disappear. Therefore, the potential endogenous choice of the managerial ownership decision for hedge funds needs to be accounted for. We propose a method for doing so in the following sub-section.

\subsection{The multi-process Probit-hazard model}

Heckman's (1979) two-stage procedure and instrumental variable estimations are commonly used to account for endogeneity. However, Heckman's approach can only apply to a Probit model and linear model relationship. Since the fund survivorship is non-linear (as discussed below), Heckman's approach is not applicable. Another approach to modeling the endogeneity issue in hedge fund manager ownership is to use instrumental variables for managerial ownership; however, it is difficult in practice to identify valid instrumental variables (Himmelberg et al., 1999). Coles et al. (2012) suggest that, in the ownershipperformance context, proxy variables, fixed effects, and instrument variables do not generally provide reliable solutions. ${ }^{10}$

\footnotetext{
${ }^{10}$ Heckman's two-stage procedure involves first estimating a standard formulation of a dich otomous choice model to obtain estimates, i.e., a Probit model and then using the estimates from the Probit model to calculate the inverse Mill's ratio which is inserted into the second stage model as an independent variable. Heckman's two-stage approach can effectively account for self-selection bias if the second stage model is a linear model. We thank William Greene for pointing this out to us. Other two-stage least square estimations are developed to deal with potential endogeneity problems in regressors in linear models and some non-linear models. However, to "instrument" potential endogenous regressors and correct potential endogeneity problems in survival time, data tend to result in inconsistent estimates when predictors from the first stage are used in the second stage regression (Terza et al., 2008). Even though Terza et al. (2008) point out consistent estimates can be obtained using the firststage estimated residuals, rather than predictors in the second stage non-linear model, the issue of implementing such an approach directly on a Probit-multiplicative hazard framework has not yet been resolved.
} 
Here we apply a joint estimation approach that explicitly incorporates and models the potential endogeneity of management participation ascribed to unobserved attributes which affect both managerial ownership decisions and the probability of fund survivorship. Not correcting for the potential endogeneity leads to biased estimates, but the joint estimation approach can eliminate bias by making the source of the bias part of the model. The latent propensity to invest personal capital into the fund, $P C_{i}{ }^{*}$, is the initial managerial ownership decision outcome specified as the Probit process:

$$
P C_{i}^{*}=c+\lambda X_{i}+\eta_{i}
$$

where $X_{i}$ represents the vector of exogenous fund governance, fee structure, and other fund attributes; $\eta_{i}$ is the random error term which is assumed to be normally distributed such that $\eta_{i} \sim N\left(0, \sigma_{\eta}\right)$. The decision outcome, whether or not to invest personal capital, $P C_{i}$, depends on the value of $P C_{i}^{*}$ relative to an implicitly defined zero-threshold:

$$
\begin{aligned}
& P C_{i}=1 \text { if } P C_{i}^{*}>0 \\
& P C_{i}=0 \text { if } P C_{i}^{*} \leq 0
\end{aligned}
$$

The conditional likelihood function for the Probit process is given by

$$
l_{i}^{p}(\eta)=\Phi\left(c+\lambda X_{i}\right)^{P C_{i}}\left(1-\Phi\left(c+\lambda X_{i}\right)\right)^{1-P C_{i}}
$$

where $\Phi(\bullet)$ is the cumulative normal density function.

The survivorship risk of the hedge fund is modeled as a logarithm of a continuous-time hazard process given by

$$
\ln h_{i}(t)=\alpha+\tau T(t)+\beta X^{*}{ }_{i}+\gamma Y_{i}(t)+\delta P C_{i}+\varepsilon_{i}
$$

where $h_{i}(t)$ represents the hazard rate between the probability of default at time $t$ over the cumulative probability of fund survival up to time $t$ for fund $i . T(t)$ denotes the baseline hazard 
fund duration dependence, also known as the piecewise-linear Gompertz spline, which is based on the transformation of the spell duration $t$, with two nodes being used in this study, i.e., $T(t)=\left(\min \left[t, v_{1}\right], \max \left[0, \min \left[t-v_{1}, t-v_{2}\right], \max \left[0, t-v_{2}\right]\right)\right.$. We set $\quad\left[v_{1}=5\right.$ year, $v_{2}=8$ year $]$ to capture the effect of the duration on the hazard rate. $X^{*}{ }_{i}$ represents the vector of time-invariant exogenous fund governance and fee structure covariates based on the literature concerning fund performance determinants which shift the baseline hazard.

The pay-out period is not included as an explanatory variable in the hazard function. The pay-out period is the period of time before investors can obtain cash back, during which the investor will not receive any return from the investment in the hedge fund. It only appears in the managerial co-investment decision process. The pay-out period depends on the settlement process, which provides the fund manager with time to prepare for withdrawals.

Although the pay-out period imposes restrictions on the investor's ability to make withdrawals of money from the fund, the length of the pay-out period is only a technical factor after the net asset value has been determined on redemption. As such, it should have no significant impact on the survivorship of hedge funds. Not including the pay-out period variable in the hazard estimation ensures that the coefficient of $\mathrm{PC}, \delta$, can be exactly identified - it places an exclusion restriction in which it explains the self-selection decision (i.e., management participation) but is unrelated to the failure of hedge funds (i.e., fund survivorship). $P C_{i}$ denotes the fund manager's personal capital, which takes the value of one if a participation decision is made and zero otherwise.

$Y_{i}(t)$ represents the vector of time-varying fund returns, volatility, and size (AUM) as fund returns and size change value during the lifetime of hedge funds. Denote the points in time that mark intervals by $\left(t_{0}, t_{1}, \ldots, t_{i}\right)$, so that $Y_{i}(t)$ is constant and equal to $Y\left(t_{1}\right)$ between $t_{0}$ and $t_{1}$, jumps to $Y\left(t_{2}\right)$ at $t_{1}$, remains constant between $t_{1}$ and $t_{2}$, jumps to $Y\left(t_{3}\right)$, et cetara. It is well 
documented that hedge fund returns exhibit a high degree of serial correlation - return smoothing is one of the sources of such correlation (Getmansky et al. 2004a). Return smoothing practices are not uncommon in the hedge fund industry, partly due to trading in illiquid assets and partly due to fund managers intentionally misreporting returns (Agarwal et al., 2011; Bollen and Pool, 2009; Getmansky et al., 2004a). Return smoothing practices can bias the riskadjusted return measures - for example, an upward bias in the Sharpe Ratio and a downward bias in volatility - causing potentially severe erosion in risk transparency. To address this potential smoothing bias, we apply Getmansky et al.’s (2004a) approach to adjust fund return smoothing. This approach is particularly appropriate for our research since the rates of fund returns and fund sizes change over time. The choice of a time-varying covariate involves the choice of a functional form for the time-dependence of the covariate. Therefore, we calculate the mean returns and standard deviation returns for every 12 months based on smoothingadjusted returns, which are then used as time-varying explanatory drivers ${ }^{11}$. By including a time-varying AUM variable, it can take advantage of the whole amount of information during the lifetime of hedge funds. Time-varying AUM is useful for another reason. In the literature, there is a debate about the association between fund managers' risk taking and fund value when fund value is below the high-water mark (Lan et al. (2013) and Buraschi et al. (2014)). Therefore, using time-varying AUM, volatility and returns during the lifetime of hedge funds can provide information about hedge funds' survival risk. The hazard model with time-varying covariates makes data structure with two nested levels, in which the unit level of observation is fund level, i.e., level 1 and time-varying covariate is level 2. The term $\varepsilon_{i}$ captures unobserved heterogeneity at the fund level that affects the hazard rate of survival and is assumed to be normally distributed as $\varepsilon_{i} \sim N\left(0, \sigma_{i}^{2}\right)$. Although one might still claim that such

\footnotetext{
${ }^{11}$ Due to the last monthly return and AUM values for some funds being less than $-100 \%$ and 0 , respectively, suggesting such funds are defunct, we remove the last month return and AUM values for such funds in order to avoid look-ahead bias when estimating the survivorship risk of hedge funds.
} 
analysis does not capture the full picture of survival risk, it seems unlikely that the potential endogeneity of the co-investment decision issue would vary systematically based on the Monte Carlo simulation experiment given in Appendix A.

Given the log-hazard equation for fund failure, the baseline survival function for each fund is given by

$$
S_{0}(t)=\exp \left\{-\int_{t_{0}}^{t} \exp (\alpha+\tau T(v)) d v\right\}
$$

where $t_{0}$ denotes the beginning of the fund. The resulting survival function, conditional on exogenous constant covariates $X_{i}$, constant covariate $P C_{i}$, and time-varying covariates $Y_{i}(t)$, and unobserved heterogeneity component $\varepsilon_{i}$ is

$$
S_{i}\left(t, X_{i}, P C_{i}, Y_{i}(t), \varepsilon\right)=\prod_{\tau=0}^{I-1}\left[\frac{S_{0}\left(t_{\tau+1}\right)}{S_{0}\left(t_{\tau}\right)}\right]^{\exp \left\{\beta X_{i}+Y_{i}(t)+P C_{i}+\varepsilon_{i}\right\}}
$$

where the spell is subdivided into I intervals within which time-varying covariates $Y_{i}(t)$ are constant. The conditional likelihood function for the hazard process is given by

$$
l_{i}^{h}(\varepsilon)=S_{i}\left(t, X_{i}, P C_{i} Y_{i}(t), \varepsilon\right)\left(h_{i}\right)^{I\left(D_{i}>0\right)}
$$

where $I\left(D_{i}>0\right)$ is an indicator function that takes the value of 1 if fund $I$ defaults, and zero otherwise.

Managerial ownership can be affected by unmeasured attributes that influence both survivorship risk and the decision to risk personal wealth. These unmeasured attributes are unobservable to investors, but fund managers themselves might be aware of them. For example, a fund manager may have private knowledge that his/her fund is at above-average risk of default - i.e., $\varepsilon_{i}$ is positive - so the fund manager may decide not to risk personal capital. The observed $P C_{i}$ is correlated with $\varepsilon_{i}$-i.e., $P C_{i}$ is endogenous to the fund hazard risk. Failure to account for this potential endogeneity will lead to biased estimates (Pindyck and Rubinfeld, 
1991). But the unobservable attributes can be eliminated by incorporating the source of the bias as part of the model.

We therefore estimate the two outcomes jointly in order to eliminate bias by assuming that the joint distribution of $\varepsilon$ and $\eta$ has a bivariate normal distribution with mean zero and variance-covariance matrix $\Omega$.

$$
\left(\begin{array}{l}
\varepsilon \\
\eta
\end{array}\right) \sim N\left(\left(\begin{array}{l}
0 \\
0
\end{array}\right),\left(\begin{array}{cc}
\sigma_{\varepsilon}^{2} & \rho \sigma_{\varepsilon} \sigma_{\eta} \\
\rho \sigma_{\varepsilon} \sigma_{\eta} & \sigma_{\eta}^{2}
\end{array}\right)\right)
$$

where $\rho$ denotes the correlation between $\varepsilon$ and $\eta$, which captures all sources of correlations for the two processes.

The significance of the estimated $\rho$ can be used to test the null hypothesis of exogenous investment of personal capital on the survivorship risk of hedge funds. In other words, the potential presence of endogeneity of management participation is decided by $\rho$, which captures the influence of unobserved information, such as fund manager motivation and capability that can jointly affect management participation decisions and hedge fund survivability processes. If the estimated $\rho$ is statistically insignificant, it suggests the fund manager's personal capital is exogenous to the hazard rate of fund survival, and the estimation of Eq.(3) alone does not suffer from endogeneity bias. However, if the coefficient on $\rho$ is statistically significant, it suggests that there could be unobserved variables that may simultaneously influence the managerial-stake decision and therefore the fund survivorship process. It is worth noting that significant correlation does not represent the causal impact of management participation on the hazard rate of fund survival, but rather the result of some other unknown attributes.

The joint estimation approach captures the linkages between the survivorship risk of hedge funds and fund managers' decision to co-invest, which takes into account that the decision of managerial ownership is endogenous and provides a measure of the marginal effect of the 
managerial ownership decision. The joint estimation for the approach of Eq.(1) and Eq.(3) is based on maximization of the joint marginal log-likelihood function by integrating the joint conditional likelihood functions, $l_{i}^{p}(\eta)$ and $l_{i}^{h}(\varepsilon)$, over the heterogeneity components $\eta$ and $\varepsilon$.

$$
L=\int_{\varepsilon} \int_{\eta} f(\varepsilon, \eta \mid \Omega)\left(\prod_{i=1}^{N} l_{i}^{h}(\varepsilon)\right)\left(\prod_{i=1}^{N} l_{i}^{p}(\eta)\right) d \eta d \varepsilon
$$

where $f(\varepsilon, \eta \mid \Omega)$ is the bivariate normal density function with variance-covariance matrix $\Omega$. The full-information log-likelihood function for the two outcomes combined is maximized using the approach of Berndt et al. (1974), as implemented in aML (Lillard and Panis, 2003).

\section{Data description}

The hedge fund data used in our analysis are obtained from the Lipper/TASS database for the period extending from January 1994 to July 2014. This period is less subject to survivorship bias because the TASS database starts reporting information on hedge fund survivorship after 1994. We eliminate funds that reported in currencies other than the US dollar, leaving a total of 11,087 US dollar denominated funds in the dataset. The TASS dataset classifies hedge funds into two categories: Live and Graveyard (hereafter Defunct). There are 2,595 Live funds and 8,492 Defunct funds in our dataset. In order to avoid backfill bias, we remove the first 12 months return and AUM information for each fund. We also drop those funds that do not report AUM, have missing characteristics, or have less than 24 months of reported return observations. This results in a final sample of 8,920 US dollar denominated funds, comprised of 1,927 Live funds and 6,993 Defunct funds. Our data also contain two types of information related to management participation: Personal Capital $(P C)$ and Personal Capital Amount $(P C A)$, where $P C$ is a binary variable indicating whether the fund manager has made a personal co-investment or not, and $P C A$ shows the actual amount of money hedge fund managers invest alongside that 
of investors. There are 810 funds that report a $P C A$ in our final fund sample. With hedge funds, manager's compensation contract is set at the funds inception and seldom changes during the life time of the fund (Agarwal et al. 2009).

Why do hedge funds disappear? Funds may liquidate or close down due to their poor performance, or hedge fund managers may voluntary stop reporting to or dropping out of a database for self-selected reasons (Horst and Berbeek, 2007). For example, funds that perform well but do not need to attract capital may stop reporting. Lipper/TASS provides a number of reasons for the disappearance of funds: (i) fund liquidations; (ii) funds no longer reporting; (iii) unable to contact; (iv) closed to new investment; (v) merged into another fund; (vi) program closed; (vii) unknown. Ackermann et al. (1999) argue that those funds no longer reporting their performance or closed to new investment should not be classified as defunct because of poor performance, but rather because they have no need to attract additional capital. Liang and Park (2010) show that it is misleading to infer that disappearance of hedge funds is equivalent to bad performance hedge funds. Horst and berbeek (2007) reports that both liquidation and voluntarily drop off from a database are more likely for hedge funds that have a poor return history, while the relationship is stronger for funds being liquidated. Lipper/TASS-further classifies. Defunct funds into seven sub-ategories: (i) fund liquidations; (ii) funds no longer reporting; (iii) unable to contact; (iv) closed to new investment; (v) merged into another fund; (vi) program closed; (vii) unknown:Ackermann al. (1999)
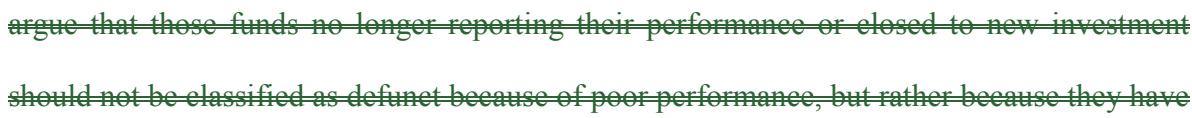

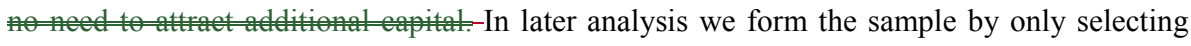
defunct funds in category (i), while the number of Live funds remains the same. We repeat the analysis for this hedge fund sample - denoted as the 'Absolute Defunct'. There are 5,161 funds in the resulting sample, 1,927 Live and 3,234 Defunct.

\section{Empirical results}




\subsection{Summary Statistics}

Table 1 presents a descriptive overview of the summary statistics and characteristics for both Live and Defunct hedge funds over the research period. Table 1 also presents the characteristies of Live and Defunct funds. Personal Capital $(P C)$ is the dummy variable that equals one if the fund manager has co-invested in the fund, zero if not. On average, $23 \%$ of managers have personal capital in their funds, which is lower than that for Defunct funds $(27 \%)$. This suggests that more managers of Defunct funds make personal co-investments than in Live funds. Co-investment of fund managers does not seem to have an impact on fund liquidation. The size of $P C A$ varies from $\$ 1$ to $\$ 300 \mathrm{~m}$. The mean amount of co-investment by fund managers is $\$ 25.38 \mathrm{~m}$ and $\$ 8.40 \mathrm{~m}$ for Live and Defunct funds, respectively. Even though on average live funds have three times as much invested, it is not necessary to establish that the higher the managerial co-investments when measured by dollars invested, the less likely funds will fail, as larger proportions of Live funds which have no invested personal capital are still live not dead.

The average (median) duration of Live funds is 8.60 (7.67) years, and the average (median) duration of Defunct funds is 5.49 (4.42) years. A Log-rank test for the differences across the two groups for the survival duration shows that the differences are significant ( $\mathrm{p}$-value $=0.000$ ).

From Table 1, we find that there is no significant difference in management fees and incentive fees between Live and Defunct funds. We also conduct a two-sample t-test to test whether investors pay higher management fees to managers who put their skin in the game. The test shows that there is no difference $(\mathrm{t}$-value $=0.7084)$, indicating the signal of managerial participation is not informative. This is equilibrium with no separation (i.e., a pooling equilibrium), i.e., the signal of managerial ownership is not informative and the equilibrium response from investors is not to pay a premium to the hedge funds where managers have skin in the game. The percentage of funds that have HWM provisions is slightly higher $(67 \%$ vs. 
$61 \%$ ) for Live funds in comparison to Defunct funds. The latter are more likely to use leverage (49.29\% vs. $57.08 \%)$. An examination of cancelation policy variables - including lock-up period and pay-out period - reveals no significant differences between the Live and Defunct funds. A much higher percentage of the Live funds (16.92\%) had a registered independent adviser (RIA) compared to the Defunct fund category (8.88\%).

\section{[Insert Table 1 here]}

\subsection{Does Managerial Ownership Matter For Fund Survivorship Risk?}

In this section, we examine whether there is a causal impact of managerial ownership on the survivorship risk of hedge funds. We jointly estimate the Probit process (examining the determinants of managerial stake decisions) and hazard rate process (examining the survivorship risk), allowing heterogeneity components to be correlated. Table 2 shows the joint estimation results of the multi-process Probit-hazard model that controls for self-selection of management participation decisions, in which Panel I displays Probit estimates for managerial participation decisions and Panel II displays hazard model estimates.

\section{[Insert Table 2 here]}

\subsubsection{Test for Endogeneity of the Managerial Ownership Variable}

The first variable of interest in Panel II of Table 2 is correlation $\rho$. The estimated correlation coefficients $\rho$ are negative and statistically significant at the $1 \%$ level $(\rho=-0.5848, t=-3.73)$. This suggests the existence of endogeneity between managerial ownership and survivorship of hedge funds, confirming that unobserved attributes influence both fund manager co-investment decisions and the survival risk of hedge funds. That is, unobserved attributes that positively affect fund managers' propensity for management participation $(\eta>0)$ tend to be negatively associated with unobserved attributes that affect survivorship risk $(\varepsilon<0)$. The statistical significance of $\underline{\rho}$ implies that the impact of managerial ownership is biased if endogeneity is not accounted for. The size of the bias depends 
on the magnitude of $\rho, \sigma_{\varepsilon}$ and the severity of the truncation ${ }^{12}$. Note that the significance of correlation is not caused by fund manager co-investments but by unobserved factors that drive both management participation and fund liquidation risk processes.

This result is consistent with Loderer and Martin (1997) who also use a simultaneous equation framework and find that the positive relationship between ownership and performance disappears when endogeneity is accounted for. Our estimation result confirms the findings of Brown et al. (2008) that regulators should take the endogenous production of information into account in evaluating the role of hedge funds; it also confirms those of Himmelberg et al. (1999) that a large fraction of the cross-sectional variation in managerial ownership is explained by unobserved firm heterogeneity, and that change in managerial ownership has no impact on firm performance. Finally, this finding is consistent with Palia's (2001) argument that managerial compensation is endogenously determined and higher management ownership is unrelated to firm value. Though the finding unobserved attributes affect both managerial ownership decision and liquidation processes is important on its own, another interesting question is what the unobserved source of variance could be. We present a test designed to identify and assess the impact of unobserved attributes in subsection 4.2.5.

4.2.2. Test for the Personal Capital Variable

\footnotetext{
${ }^{12}$ The expected hazard rate for fund $i$ given that fund managers make ownership decisions is: $E\left[\ln h_{i}(t) \mid P C_{i}=1\right]=\alpha+\tau T(t)+\beta X_{i}+\gamma Y_{i}(t)+\delta+E\left(\varepsilon_{i} \mid P C_{i}=1\right)$

$=\alpha+\tau T(t)+\beta X_{i}+\gamma Y_{i}(t)+\delta+E\left(\varepsilon_{i} \mid \eta_{i}>-c-\lambda x_{i}\right)$

$=\alpha+\tau T(t)+\beta X_{i}+\gamma Y_{i}(t)+\delta+\rho \sigma_{\varepsilon}\left[\phi\left(c+\lambda x_{i}\right) / \Phi\left(c+\lambda x_{i}\right)\right]$

where $\phi$ and $\Phi$ denote probability density function and cumulative probability function of the standard normal distribution, respectively.

The expected hazard rate for fund $i$ given that fund managers do not make ownership decisions is:

$E\left[\ln h_{i}(t) \mid P C_{i}=0\right]=\alpha+\tau T(t)+\beta X_{i}+\gamma Y_{i}(t)+E\left(\varepsilon_{i} \mid P C_{i}=0\right)$

$=\alpha+\tau T(t)+\beta X_{i}+\gamma Y_{i}(t)+E\left(\varepsilon_{i} \mid \eta_{i} \leq c+\lambda x_{i}\right)$

$=\alpha+\tau T(t)+\beta X_{i}+\gamma Y_{i}(t)+\rho \sigma_{\varepsilon}\left[-\phi\left(c+\lambda x_{i}\right) /\left(1-\Phi\left(c+\lambda x_{i}\right)\right)\right]$

The difference between the expected hazard rate with and without managerial ownership is:

$E\left[\ln h_{i}(t) \mid P C_{i}=1\right]-E\left[\ln h_{i}(t) \mid P C_{i}=0\right]=\delta+\rho \sigma_{\varepsilon}\left[\phi\left(c+\lambda x_{i}\right) / \Phi\left(c+\lambda x_{i}\right)\left(1-\Phi\left(c+\lambda x_{i}\right)\right)\right]$

Since both $\sigma_{\varepsilon}$ and truncation term $\left[\phi\left(c+\lambda x_{i}\right) / \Phi\left(c+\lambda x_{i}\right)\left(1-\Phi\left(c+\lambda x_{i}\right)\right)\right]$ are positive, and $\rho \neq 0$, the impact of estimated coefficient $\delta$ is biased by $\rho \sigma_{\varepsilon}\left[\phi\left(c+\lambda x_{i}\right) / \Phi\left(c+\lambda x_{i}\right)\left(1-\Phi\left(c+\lambda x_{i}\right)\right)\right]$.
} 
The coefficient of managerial ownership $P C$ shown in Table 2 is insignificant $(P C=0.1535, t=0.86)$, indicating that hedge fund managers investing in the funds they manage do not statistically reduce the risk of fund survivorship when taking endogeneity into account. This is consistent with the results reported in Boyson (2010) and Liang and Park (2010), but contradicts the widespread perception that if investors select funds from those managers who have skin in the game, they substantially improve their odds of beating the market. Conventional thinking suggests that hedge fund managers invest a significant propertion of their assets in a fund as they are profit maximizing and recognize their own skill. This over-simplification leads to a misunderstanding about the impact of own investments in a fund. We interpret this apparently contrasting result as being partly due to the existence of self-selection bias and inappropriate treatment of management participation decisions as exogenous, and partly due to the asymmetric reward structure and the focus on abselute returns.-Fung and Hsieh (1999) point out that under extreme circumstances fund managers have the option to expose their personal wealth to losses by taking excessive risk, driven by the adverse gambling incentive embedded in the asymmetric reward structure of their compensation contracts. Therefore, managers with skin in the game may well find that the incentive to take risks to achieve a performance fee is in excess of what they can achieve through capital gains on their investment in their fund. When the performance fee is a percentage of the hurdle rate, this can theoretically happen wherever the skin in the game percentage is smaller than the incentive percentage.

The insignificance of managerial ownership on fund survivorship performance conforms to a well-developed strand of theories on managerial myopic behavior which shows that company managers tend to underinvest in high net present value but long term projects if compensation contracts only consist of short term (eash) plans. Narayanan (1996) derives three testable hypotheses for why companies benefit from the existence of both cash and stock 
incentive schemes in executive compensation packages, in which long term stock compensation can resolve the problem of myopic investment. The short term incentive mechanism is the basis of hedge fund management; therefore, the impact of managerial ownership is dependent on incentive packages. In regular companies, executive managers are likely to have incentives to invest for the long term (i.e., not to generate high short term income at the cost of long term performance), while hedge fund managers may have incentives to maximize shert term profit at the cost of long term survivorship performance. This is because a large propertion of fund managers' compensation package is asseciated with short term performance (percentage of annual profit).

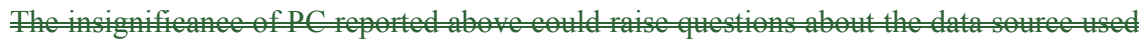
in this study. Given the key variable PC provided by TASS is only snapshot, could the endogenously determined co-investment decision be resolved if time-series $\theta$ - co-investment

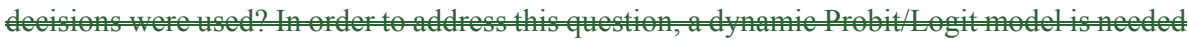
andyzer in $P C_{i t}=1$ if a

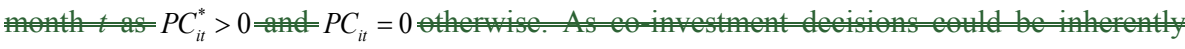
persistent and dymamie, initial deeision eondition $P C_{i 0}$ is eorrelated with unobsed faetors that can affect $P C_{i t}$. If $P C_{i 0}$ is taken as exogenous, estimators can still be inconsistent even if the timeseries of $P C_{i t}$ are used insteat, whieh is alled the initial eonditions problem. Afrarwal et al. (2009) assume that hedge fund managers can reinvest all of the incentive fees into the

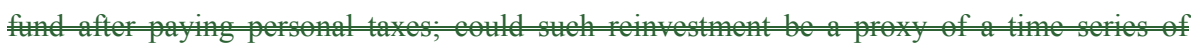

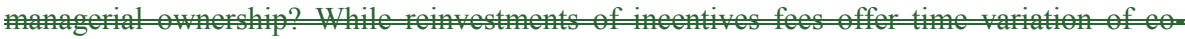
investment, the momie or statistieals signifieanee differential from hedo fund retun risks is not clear-eut (for details see Section 4.3 ).

Panel I of Table 2 also reports additional coefficient estimations for the multi-process Probit-hazard model. We employ the following determinants to explain the managerial stake: 
management fee, incentive fee, HWM, leverage, lock-up period, pay-out period, RIA, category and initial AUM. All variables are significantly related to the managerial stake. Management fee is negative and significant, suggesting that with a lower management fee, fund managers are more likely to invest their own capital. Management fee is also an asset-based fee that provides hedge fund managers with a steady income stream. It can be considered as at eompenent of managerial ownership, therefore with a higher management fee, fund managers are less likely to invest their own capital. Higher incentive fees encourage managers to participate. The hedge fund manager is a wealth maximizer, so-should focus on the element which is most likely to make him/her the greatest financial gain. The positive coefficient from the incentive fee and the negative from the management fee indicate that the former is more impertant.

One of the aspects that differentiate hedge funds from other investment vehicles is the use of leverage. The estimation result shows a positive link between leverage and manager incentives for co-investment. If the manager has skill, or believes he/she or she has skill, it is in his/her best interests to maximize that skill through leverage. The manager will not be able to do this as effectively, in his/her personal capacity, as in a collective investment vehicle; such a vehicle also has the advantages of limited liability.

Recall that the lock-up period refers to the time during which the invested money cannot be withdrawn. The positive impact of the lock-up period on co-investment is because that lockup period reduces fund-flow sensitivity, contributing to more stable fund management and management freedom in pursuing investment strategies (Baba and Goko, 2009), hence more possibilities in investing in illiquid asset classes. Consequently, longer lock-up periods should encourage fund managers to invest in their own funds, $s_{2}$. Though, like the lock-up period, the pay-out period is a technical function of the settlement of redemptions,-the pay-out period is the period during which investors will not receive any returns on fund performance. Therefore 
if the fund manager has persenal capital invested, as an investor, he/she may dislike a longer and high. This may be attributable to more professional hedge fund managers registering onshore and being more likely to invest in their own funds. The positive coefficient for the

\subsubsection{Test for Other Control Variables}

Also reported in Table 2 are estimations for the hazard process model. We employ several variables used in survival analysis that may influence the attrition rates of hedge funds suggested in the hedge fund literature on fund characteristics, such as Agarwal et al. (2009), Brown et al. (2001), Goetzmann et al. (2003), and Panageas and Westfield (2009).

These variables can be categorized into four groups: (i) managerial participation $-P C$ and $P C A$; (ii) governance and fee structure - management fee, incentive fee, HWM, leverage, and RIA; (iii) cancelation policy - lock-up periods and pay-out periods; and (iv) fund performance - fund returns and size. The survivorship risk for the first five years rises sharply $\left(\tau_{1}=0.4090, t=13.1\right)$, after which it remains stable between years five and eight $\left(\tau_{2}=0.000, t=0.00\right)$. After eight years, however, the survivorship risk again rises slightly $\left(\tau_{3}=0.0696, t=6.32\right)$.

The level of management fees does not have a statistically significant impact on fund survivorship. However, the loading for the incentive fees variable is positive and significant at the $1 \%$ level, implying that high incentive fees increase the hazard rate of fund survivorship $\left(\beta_{\text {incentive }}=1.5608, t=4.54\right)$. Contributions to the hedge fund literature on the role of without HWM, which confirms the argument that HWM may cause managers to pursue highrisk investment strategies (Goetzmann et al., 2003). The leverage has no effect on fund survivability because hedge fund leverage is significantly less than that of depository institutions and investment banks (Gupta and Liang, 2005) due to the market discipline imposed by their creditors and investors. 
With respect to the lock-up period, our results indicate that a longer lock-up $\left(\beta_{\text {lock }}=0.0590, t=3.26\right)$ can increase the survivorship-hazard rate of funds, ${ }_{2}$ which is consistent with Our results lend support to the argument proposed in Baba and Goko (2009) that investors dislike less liquidity, so the longer the lock up period the less likely they are to invest, which in turn destabilizes fund management. Agarwal et al. (2009). also provide evidence that a longer lock up period is associated with fund flows, and therefore has a negative impact on fund survival.Lastly, there is statistically significant evidence that funds with RIAs are less likely to fail than non-RIA funds $\left(\beta_{\text {ria }}=-0.4670, t=-6.40\right)$. Aragon et al. (2013) show evidence that some advisers actively avoid registration by changing fund characteristics. Therefore, for funds that are registered with SEC, we expect that after qualifying within the strict guidelines the firm is capable enough to handle the adviser's investments. There is no significant difference between funds of funds and those funds in other categories $\left(\beta_{f o f}=-0.0029, t=-0.06\right)$.

Regarding the impact of time-varying covariates, fund annual returns have a significant influence on the risk of fund survivorship in the expected direction. $T$ the statistically significant loading of fund annual returns $\left(\gamma_{r}=-1.0450, t=-26.6\right)$ suggests that a $1 \%$ increase in annual returns leads to a $3.52 \%$ decline in fund failure. The loading of fund annual return volatility is positive and significant $\left(\gamma_{\sigma}=0.7474, t=24.5\right)$ - in line with previous findings that higher return and lower volatility tend to have lower liquidation probabilities (see for example Baba and Goko, 2009; Baquero et al., 2005; Brown et al., 2001; Liang, 2000). Fund size is negatively associated with survivorship risk, indicating that funds with larger and more stable assets are less likely to be liquidated $\left(\beta_{\text {size }}=-0.4833, t=-15.0\right)$.

\subsubsection{Decomposing Managerial Stakes}


In this subsection, we present a test that explicitly investigates what the unobserved attributes could be. We apply the approach of Khorana et al. (2007) to decompose the managerial ownership decision into observed and unobserved fund attributes. We first estimate Eq.(1) by regressing managerial ownership decision $P C_{i}$ on the set of observed fund characteristics $X_{i}$ to generate observed attributes $\Phi\left(\hat{\lambda} X_{i}\right)$ and use the estimated residuals as unobserved attributes, i.e., $P C_{i}-\Phi\left(\hat{\lambda} X_{i}\right)$, where $\Phi(\bullet)$ denotes the cumulative normal distribution. We then estimate the impact of unobserved attributes for management participation decision on hedge fund survivorship risk. That is,

$$
\ln h_{i}(t)=\alpha+\tau T(t)+\delta_{1} P C_{u n b}+\beta X_{i}^{*}+\gamma Y_{i}(t)+\varepsilon_{i}
$$

where $P C_{u n b}=P C_{i}-\Phi\left(\hat{\lambda} X_{i}\right)$

If the coefficient of the unobserved component is significant, it implies that managerial stakes contain information that influences the fund survivorship rate but remains unobserved. The survivorship risk estimation results are presented in Table 3.

[Insert Table 3 Here]

We find that the estimated coefficient on unobserved attributes is negative and statistically significant from zero $\left(P C_{u n b}=-0.1777, t=-5.36\right)$, which implies that the unobserved attributes can reduce the likelihood of hedge fund liquidation. As this result is in line with that for the significant negative correlation between management participation and fund liquidation, we view that the unobserved attributes can be interpreted as fund managers' investment IQ or skill. This interpretation is based on the following argument. Suppose a fund manager with a higher IQ is more likely to invest personal stakes; and it is also likely that a fund with a higher IQ manager is less likely to fail. Thus if managerial ownership decision can be viewed as a signal of a higher IQ, such decisions may be deemed worthy being copied by lower skilled 
managers. Given that the costs of copycatting with respect to rewards from direct and indirect incentives are relatively small, lower skilled fund managers could also be motivated to send such a signal to investors, making management participation decisions be incentive incompatible and non-informative. Could fund managers' characteristics be used as proxy for unobserved IQ or skill? Chevalier and Ellison (1990) provide evidence that manager's SAT score, MBA degree, age, tenure are somehow associated with fund performance. The fact that the explanatory power is very low $\left(R^{2}=0.03\right)$ in their paper suggests that such characteristics explain little variation in IQ/skill, i.e., insufficiently related to the unobserved investment skill.

\subsubsection{Personal Capital Commitment}

In the above subsections we treat managerial participation as a binary decision: the fund manager either invests in his/her fund or not. Could the endogenously determined coinvestment decision be resolved if time series of co-investment decisions were used? In the context of corporate finance, Leland and Pyle (1977) explain that the information content of a manager's participation is related to how far he is willing to "stick his neck out." Therefore, we further investigate whether this is the case for the hedge fund industry. Unlike the mutual fund industry, hedge fund managers are not required to report their personal investments under SEC regulations, so the available dataset is based on voluntary reporting. Only $10 \%$ of hedge funds in the Lipper/TASS database have reported a personal capital amount $(P C A)$. Consequently prior empirical evaluation of the impact of managerial ownership on the failure of hedge funds uses $P C$ as a measure of managerial ownership. A paper by Aragon and Nanda (2011) uses $P C A$ to test whether having a personal investment in the fund influences a manager's risk-taking behavior and finds that risk-shifting is less evident among managers with larger investments of $P C$ in the fund. 
As a robustness test, we replace the $P C$ variable with $P C A$, which is used to explore the impact of the degree of 'skin in the game' on a fund's survival. As statedearlier, this is in response to a concern that using a binary indicator for PC may not fully capture the effect of co-investment mechanisms on a fund's survival. -We jointly estimate Eq.(3) but substitute covariates remain the same, i.e., $\ln h_{i}(t)=\alpha+\tau T(t)+\beta X_{i}^{*}+\gamma Y_{i}(t)+\delta\left(\ln P C A_{i}\right)+\varepsilon_{i}$ with linear OLS regression for $P C A$, i.e., $\ln P C A_{i}=c+\lambda X_{i}+\eta_{i}$. As in the Probit-hazard model, $\varepsilon$ and $\eta$ are also assumed to follow a bivariate normal distribution with mean zero and variance-covariance matrix $\Omega$. The estimations are presented in Table 4 .

\section{[Insert Table 4 Here]}

Our results continue to hold for this more restrictive sample. The loading of $P C A$ is not statistically significant, indicating that high levels of personal investment in funds do not reduce fund liquidation risks. Although this result does not support the traditional view that a management stake has a positive association with hedge fund survival, it does not undercut the logic. Having limited managerial ownership does not necessarily point to the failure of managerial incentive. For example, investors would hardly commit a major share of their personal wealth into investments that seem to fail. By the same token, it is possible that managers prefer not to invest extensively in funds or strategies they deem likely to fail. The estimation results show that the coefficients of most governance, fee structure and cancelation policy covariates are comparable, regardless of the measure of managerial stakes.

4.3. Managerial Stakes as an Exogenous Variable: Test using the Single Hazard Model

The insignificance of $\mathrm{PC}$ reported above could raise questions about the data source used in this study. Given the key variable PC provided by TASS is only snapshot, could the endogenously determined co-investment decision be resolved if time series of co-investment decisions were used? In order to address this question, a dynamic Probit/Logit model is needed 
that the $P C$ variable is exogenous, as commonly used in the prior literature. Table 5.a reports the estimation results of the single hazard rate process without controlling for self-selection which is specified in Eq.(3).

\section{[Insert Table 5.a here]}

We observe that the managerial stake covariate, $P C$, is statistically significant and negative $\left(\beta_{p c}=-0.2234, t=-4.23\right)$ under this specification. This is not surprising, and is consistent with the conventional view that survivorship risk is lower for these-funds whose managers make a personal capital commitment to their funds. But after comparing the results for the single process estimation with those of joint estimation, we observe that these findings may incorporate an overestimation of the effects of managerial ownership if self-selection bias is ignored. With respect to the remaining covariates, we find higher incentive fees; longer lockup periods and higher return volatility all signifieantly raise the probability of liquidation, whereas RIA, fund retmrns and AUM have the opposite effect. There is no significant difference between fund of funds and funds in other categories, all of which are consistent with our priors.

Agarwal et al. (2009) examine the role of managerial incentives and present evidence suggesting that the reinvestment of incentive fees by managers can be a proxy measure for managerial ownership and "create fewer endogeneity concerns than typically arise in a corporate finance setting". Assuming that hedge funds with higher level of managerial ownership are associated with superior performance, we expect to observe more reductions in survival risk for higher level reinvestments. To test this hypothesis, we re-estimate the single process hazard model, replacing $\mathrm{PC}$ with a reinvestment time-variant variable, as measured by the cumulative value of the incentive fee reinvested together with the returns on it at any point in time, assuming that the hurdle rate is the sign of hedge fund returns (i.e., if hedge funds return is positive, the manager receives incentive fees and zero otherwise).

[Insert Table 5.b here] 
To estimate the impact of time-varying reinvestment on fund survival risk, we use the specification similar to the estimation results presented in Table 5.a, with one variable change and the estimation results are presented in Table $5 \mathrm{~b}$. The coefficient on reinvestment (representing managerial ownership) is statistically significant from zero but, surprisingly, positive $\left(\beta_{\text {ownership }}=1.7494, t=50.0\right)$ with unusual high t-statistics suggesting the cumulative reinvestment variable may be collinear with AUM. Further, inconsistent with the view that higher volatility of fund returns is associated with higher survival risk, the coefficient on fund return volatility becomes statistically insignificant from zero $\left(\beta_{\text {volatility }}=0.0206, t=0.39\right)$, while both the sign and significance of other time-varying coefficients on returns and size remain the same in this specification. We interpret the results as evidence of managerial ownership being a proxy for unobserved fund managers' motivations. The fact that the coefficient on volatility becomes insignificant seems to suggest that the reinvestment incentive fee measure and volatility are picking up a common phenomenon (Fung and Hsieh, 1999). In general, it is likely that the causal effect of managerial ownership in previous literature could come from not controlling unobserved fund managers' motivations.

\subsection{Robustness Test: using the Absolute Defunct Fund Sample}

As noted, the TASS database classifies its Defunct hedge funds into seven sub-categories based on their reasons for failure - liquidation is not the only reason why hedge funds drop out of the live fund category (Getmansky et al., 2004b). Some Defunct funds in the Graveyards category may choose to exit from the TASS database, not because of poor performance but rather having no incentive to report to TASS (Ackermann et al., 1999; Baquero et al., 2005).

Liang and Park (2010) also point out that it might be misleading to regard all the funds in the Graveyard category as failed ones in survival analysis. But, it is generally agreed that those funds falling into the liquidation category are fail funds because they tend to suffer from 
negative returns and high volatility. Therefore, we restrict our analyses to this sub-category, namely the Absolute Defunct sample, in order to verify that our estimation results do not suffer from different classifications for TASS Graveyard fund sample selectivity issues. We repeat our analysis with this restricted sample using the multi-process Probit-hazard model. The estimation results are presented in Table 6 .

\section{[Insert Table 6 Here]}

We find that the loading on the $P C$ variable remains insignificant $\left(P C_{\text {Absolute }}=0.0480, t=0.32\right)$ in the multi-process Probit-hazard model, demonstrating that our previous finding, that managerial ownership has no association with the disappearance of hedge funds, is not subject to sample choices.

The loading on negative values of $\rho$ continues to show a significant negative value $(\rho=-0.4327, t=-2.61)$, confirming that there are unobserved variables that simultaneously influence the co-investment decision and fund liquidation. None of our estimation results appears to be affected by different TASS Graveyard fund samples, suggesting that it is unlikely that our results are affected by different defunct fund classification problems.

\section{Conclusions}

Empirical corporate finance research has shown that managerial ownership reduces agency conflicts between investors and corporate managers Investors expect hedge fund managers to invest their personal wealth, hoping to align their incentives with the interests of both parties, thereby reducing the agency problem. The decision whether to commit personal stakes is largely at the discretion of fund managers themselves; as such it may mitigate the expected effects of managerial stakes on hedge fund survivorship risk. We generally cannot observe information on why fund managers make co-investment decisions. Such decisions tend to be 
intertwined between unobservable fund managers, skill and motivation with fund liquidation, which are far from innocuous. When taking the relationship between the survivorship risk of hedge funds and managerial ownership decision into account, we find that a fund manager's decision of having skin in the game fails to predict hedge fund longevity because we cannot rule out the possibility that fund managers could be motivated by direct incentive fees as well as higher indirect incentives. This would suggest the signal of management participation decision tends not to be informative for fund performance. Therefore, management participation should not be the sole investment decision for investors. Instead investors should focus more on management, incentive structures, and after-fee performance.

This study complements both theoretical and empirical researches that investigate the impact of incentive schemes on the hedge fund industry. Our results may help in understanding the apparently contradicting results of previous studies, which fail to consider an endogeneity bias. This paper highlights the importance of accounting for endogenous information that has been pointed out in Brown et al. (2008). We confirm the roles of fund returns, size, incentive fees, HWM and lock-up provisions in predicting hedge fund failure. Performance and size are important determinants of fund survivorship, regardless of whether we use a full sample of funds or an Absolute Defunct fund sample.

Our study has several implications. First, the relationship between hedge fund managers and investors appears to form a typical agency relationship, which has potentially important implications for the application of agency theory to the hedge fund industry. There is a tension between obtaining interest alignment benefits and restraining fund managers' incentives for excess risk taking in order to attract and increase the size of their fund (Aggarwal and Jorion, 2010). The commitment of personal capital by fund managers by itself may not be the optimal solution to align the incentives of fund managers and fund investors. This is mainly because 
hedge fund managers' compensation structure incorporates the incentive to maximize the present value of direct and indirect incentive fee income.

Second, the findings are relevant both to investors and regulators. After the 2007-2009 financial crisis, the hedge fund industry faced much greater scrutiny. There have been arguments about whether or not disclosure of managerial ownership should be made mandatory - see Khorana et al. (2007) for a summary. Our results, however, suggest that ownership disclosure is immaterial for investors. Under voluntary disclosure, hedge funds might reveal a suboptimal level of information to investors (Coffee, 1984). Based on information asymmetry models, Stiglitz (2002) shows that the private provision of information tends to be subject to market failure. The results of our study are consistent with the argument that disclosure of management stakes provided by hedge funds cannot be taken at face value. 


\section{Acknowledgments}

We are grateful to Stephen Brown Helen Bollaert, Simba Chang, Eric Debodt, Giuseppe DeFeo, Joseph Fan, William Greene, Paul Healy, Jens Jackwerth, Stan Panis, Markus Schmid, Armin Schwienbacher and David Yermack, as well as seminar participants at the University of Western Australia, University of Queensland, Curtin University and SKEMA (Lille, France), for helpful discussions and comments. We are also grateful to Mila Getmansky for providing us with the return smoothing code. We are responsible for all errors. 


\section{References}

Ackermann, C., McEnally, R., Ravenscraft, D., 1999. The performance of hedge funds: Risk, return, and incentives. Journal of Finance 54, 833-874.

Agarwal, V., Daniel, N., Naik, N., 2009. Role of managerial incentives and discretion in hedge fund performance. Journal of Finance 64, 2221-2256.

Agarwal, V., Daniel, N., Naik, N., 2011. Do hedge funds manage their reported returns? Review of Financial. Studies. 24, 3281-3320.

Aggarwal, V., Jorion, P., 2010. The performance of emerging hedge funds and managers. Journal of Financial Economics. 96, 238-256.

Ang, J., Cole, R., Lin, J., 2000. Agency costs and ownership structure. Journal of Finance 55, $81-106$

Aragon, G., Liang, B., Park, H., 2013. Onshore and offshore hedge funds: are they twins? Management Science 60, 74-91.

Aragon, G., Nanda, V., 2011. Tournament behavior in hedge funds: High-water marks, fund liquidation, and managerial stake. Review of Financial Studies 24, 937-974.

Baba, N., Goko. H., 2009. Hedge fund survival: Non-normal returns, capital outflows, and liquidity. Journal of Financial Research 32, 71-93.

Baquero, G., Horst, J., Verbeek, M., 2005. Survival, look-ahead bias, and persistence in hedge fund performance. Journal of Financial Quantitative Analysis 40, 493-517.

Basak, S., Pavlova, A., Shapiro, A., 2007. Optimal asset allocation and risk shifting in money management. Review of Financial Studies 20, 1583-1621.

Berndt, E., Hall, B., Hall, R., Hausman, J., 1974. Estimation and inference in nonlinear structural models. Annals of Economic and Social Measurement. 3, 653-665.

Bollen, N., Pool, V., 2009. Do hedge fund managers misreport returns? Evidence from the pooled distribution. Journal of Finance 64, 2257-2298.

Boyson, N., 2010. Implicit incentives and reputational herding by hedge fund managers. Journal of Empirical Finance 17, 283-299.

Brown, S., Goetzmann, W., Ibbotson, R., 1999. Offshore hedge funds: Survival and performance 1989-1995. Journal of Business 72, 91-118.

Brown, S., Goetzmann, W., Liang, B., Schwarz, C., 2008. Mandatory disclosure and operational risk: Evidence from hedge fund registration. Journal of Finance 6, 2785-2851. 
Brown, S., Goetzmann, W., Park, J., 2001. Careers and survival: Competition and risk in hedge fund and CTA industry. Journal of Finance 56, 1869-1886.

Buraschi, A., Kosowski, R., Sritrakul, W., 2014. Incentives and endogenous risk taking: A structural view on hedge fund alphas. Journal of Finance 69, 2819-2870.

Carpenter, J., 2000. Does Option Compensation Increase Managerial Risk Appetite? Journal of Finance 55, 2311-2331.

Chevalier, J., Ellison, G., 1999. Are some mutual fund managers better than others? Crosssectional patterns in behavior and performance. Journal of Finance 54, 875-899.

Coffee, J., 1984. Market failure and the economic case for a mandatory disclosure system. Virginia Law Review 70, 717-753.

Coles, J., Lemmon, M., Meschke, J., 2012. Structural models and endogeneity in corporate finance: the link between managerial ownership and corporate performance. Journal of Financial Economics 103, 149-168.

Cumming, D., Dai, N., Johan, S., 2015. Are hedge funds registered in Delaware different?. Journal of Corporate Finance, 35, 232-246.

Dangle, T., Wu, Y., Zechner, J., 2008. Market discipline and internal governance in the mutual fund industry. Review of Financial Studies 21, 2307-2343.

Das, S., Sundaram, R., 2002. Fee speech: Signaling, risk-sharing, and the impact of fee structures on investor welfare. Review of Financial Studies 15, 1465-1497.

Demsetz, H., Villalonga, B., 2001. Ownership structure and corporate performance. Journal of Corporate Finance 7, 209-233.

Drechsler, I., 2014. Risk choice under High-water Marks. Review of Financial Studies 27, 2052-2096.

Foster, D., Young, H., 2010. Gaming performance fees by portfolio managers. The Quarterly Journal of Economics. 1435-1458.

Fung, W., Hsieh, D., 1999. A primer on hedge funds. Journal of Empirical Finance 6, 309331.

Gervais, S., Lynch, A., Musto, D., 2005. Delegated Monitoring of Fund Managers: An Economic Rationale, Review of Financial Studies 18, 1139-1169 (lead article).

Getmansky, M., Lo, A., Makarov, I., 2004a. An econometric model of serial correlation and illiquidity in hedge funds returns. Journal of Financial Economics 74, 529-609.

Getmansky, M., Lo, A., Mei, S., 2004b. Sifting through the wreckage: Lessons from recent hedge-fund liquidations. Journal of Investment Management 2, 6-38. 
Gillan, S., 2006. Recent developments in corporate governance: An overview. Journal of Corporate Finance, 12, 381-402.

Goetzmann, W., Ingersoll, J., Ross, S., 2003. High-water marks and hedge fund management contracts. Journal of Finance 58, 1685-1718.

Gompers, P., Lerner, J., 1999. An analysis of compensation in the U.S. venture capital partnership. Journal of Financial Economics 51, 3-44.

Gupta, A., Liang, B., 2005. Do hedge funds have enough capital? A value-at-risk approach. Journal of Financial Economics 77, 219-253.

Heckman, J., 1979. Sample selection bias as a specification error. Econometrica, 47, 153-161.

Himmelberg, C., Hubbard, R., Palia, D., 1999. Understanding the determinants of managerial ownership and the link between ownership and performance. Journal of Financial Economics $53,353-384$.

Huberman, G., Kandel, S., 1993. On the incentives for money managers: A signalling approach. European Economic Review 37, 1065-1081.

Khorana, A., Servaes, H., Wedge, L., 2007. Portfolio manager ownership and fund performance. Journal of Financial Economics 85, 179-204.

Jensen, M., Meckling, W., 1976. Theory of the firm: managerial behavior, agency costs and ownership structure. Journal of Financial Economics 3, 305-360.

Lan, Y., Wang, N., Yang, J., 2013. The economics of hedge funds. Journal of Financial Economics 110, 300-323.

Leland, H., Pyle, D., 1977. Informational Asymmetries, Financial Structure, and Financial Intermediation. Journal of Finance 32, 371-387.

Liang, B., 2000. Hedge funds: The living and the dead. Journal of Financial Quantitative Analysis 35, 309-325.

Liang, B., Park, H., 2010. Predicting hedge fund failure: A comparison of risk measures. Journal of Financial Quantitative Analysis 45, 199-222.

Lillard, L., Panis, C., 2003. aML Multiprocess Multilevel Modeling Statistical Software. Version 2.0. Econware, Los Angeles, California.

Lim, J., Sensoy, B., Weisbach, M., 2016. Indirect incentives of hedge fund managers. Journal of Finance 71, 871-918.

Loderer, C., Martin, K., 1997. Executive Stock Ownership and Performance: Tracking Faint Traces. Journal of Financial Economics 45, 223-255.

McConnell, J., Servaes, H., 1990. Additional evidence on equity ownership and corporate values. Journal of Financial Economics 27, 595-612. 
Morck, R., Shleifer, A., Vishny, R., 1988. Management ownership and market valuation: An empirical analysis. Journal of Financial Economics 20, 293-315.

Narayanan, M., 1996. Form of compensation and managerial decision horizon. Journal of Financial Quantitative Analysis 31, 467-475.

Ozik, G., Sadka, R., 2015. Skin in the game versus skimming the game: Governance, share restrictions, and inside flows. Journal of Financial Quantitative Analysis 50, 1293-1319.

Palia, D., 2001. The endogeneity of managerial compensation in firm valuation: A solution. The Review of Financial Studies, 14, 735-764.

Panageas, S., Westfield, M., 2009. High-water marks: High risk appetites? Convex compensation, long horizons, and portfolio choice. Journal of Finance 64, 1-36.

Pindyck, R., Rubinfeld, D., 1991. Econometric models and economic forecasts. McGraw-Hill Inc., New York, NY.

Shadab, H., 2013. Hedge fund governance. Stanford J. Law Business Finance, 19, 144-204.

Stiglitz, J., 2002. Information and change in the paradigm in economics. American Economic Review 92, 460-501.

Terza, J., Basu, A., Rathouz, P., 2008. Two-stage residual inclusion estimation: Addressing endogeneity in health econometric modeling. Journal of Health Economics 27, 531-543.

Vanasco, V., 2014. Information Acquisition vs. Liquidity in Financial Markets. Working Paper, Stanford University.

Yin, C., 2016. The optimal size of hedge funds: Conflict between investors and fund managers. Journal of Finance 71, 1857-1894. 


\section{Appendix A: Monte Carlo simulation design and setting}

Our emphasis in this simulation experiment is on the bias in the estimator of managerial participation on hedge fund survival risk that may arise if potential endogeneity of participation is ignored. The management participation decision process employs a latent variable specification. The latent variable is given by $y_{i}^{*}=\lambda X_{i}+\eta_{i}$ where $X_{i}$ is a set of exogenous variables, $\eta_{i} \sim N\left(0, \sigma_{\eta}^{2}\right)$ and the observable management participation variable $y_{i}=1$ if $y_{i}^{*}>0$ and $y_{i}=0$ if $y_{i}^{*} \leq 0$. The specification of fund survivorship risk process employs a parametric Weibull hazard model in that $h_{i}(t)=\lambda v t^{\nu-1}\left(\exp \left(\delta Z_{i}+\varepsilon_{i}\right)\right)$ where $\lambda v t^{\nu-1}$ is the baseline hazard, $Z_{i}$ is the set of exogenous variables, and $\varepsilon_{i} \sim N\left(0, \sigma_{\varepsilon}^{2}\right)$. As explained in Section 2, the model requires taking the endogeneity issue for management participation $y_{i}$ into account. Therefore we allow a correlation structure between $\eta_{i}$ and $\varepsilon_{i}$ to follow a bivariate normal distribution with correlation $\rho$, capturing the omission of some important factors that affect both management participation decision and fund survivorship risk processes. Note we do not include $y_{i}$ when simulating survival time for the Weibull hazard model. However, the simulated $y_{i}$ will be included in the Weibull hazard estimation process as an explanatory variable afterwards. This allows us to examine the impact of $y_{i}$ on simulated survival risk when actually there is no impact at all.

The parameter choices in the simulation experiment and data generating process are as follows. We set the number of observations $\mathrm{N}=1000: 1000: 10000$ and the number of simulations $\mathrm{M}=1000$. We draw the random error terms $\eta_{i}$ and $\varepsilon_{i}$ from a bivariate normal distribution with $\sigma_{\eta}=0.6, \sigma_{\varepsilon}=1.0$, and $\rho=-0.9: 0.05: 0.9$. We then simulate the binary management participation decision, $y_{i}$, from a binomial distribution with probability $\pi_{i}$, which is given by $\pi_{i}=\Phi^{-1}\left(y_{i}^{*}\right)=\Phi^{-1}\left(\theta X_{i}+\eta_{i}\right)$ where $\Phi^{-1}(\bullet)$ is the inverse cumulative 
normal distribution function. The single exogenous regression $X_{i}$ is drawn from a chi-square distribution with 6 degrees of freedom and $\theta=1$. Next, we simulate the survival risk for hedge funds. In doing so we need to generate survival time $T_{i}$ and censoring time $L_{i}$. Note survival time and censoring time are independent. Survival time $T_{i}$ follows a Weibull distribution and is simulated by

$$
T_{i}=\left(-\frac{\log (U)}{\lambda \exp \left(\delta Z_{i}+\varepsilon_{i}\right)}\right)^{1 / v}
$$

where $U$ follows a uniform distribution with $U \sim U[0,1]$, scale parameter $\lambda=0.02$, shape parameter $v=2$, the exogenous variable $Z_{i}$ is drawn from standard normal distribution, and $\delta=1$. Censoring time $L_{i}$ is simulated from an exponential distribution $E\left(g_{i}\right)$ with $g_{i}=\mu\left(T_{i}\right)$. Having generated both survival time $T_{i}$ and censoring time $L_{i}$, we can decide the censoring variable $C_{i}$ such that $C_{i}=I\left(T_{i} \leq L_{i}\right)$. As a result, the simulated data is a triplet of $\left(\tau_{i}, C_{i}, Z_{i}\right)$ which is ready for conducting the Weibull hazard model estimation, where $\tau_{i}=\min \left(T_{i}, L_{i}\right)$. Finally, we conduct a hazard model estimation based on the simulated triplet data and $y_{i}$. Note, in this final step we deliberately include $y_{i}$ as a supposed exogenous explanatory variable, such that $h_{i}(t)=\lambda v t^{\nu-1}\left(\exp \left(\gamma Y_{y}+\delta Z_{i}+\varepsilon_{i}\right)\right)$, where the simulated coefficient $\gamma$ can enable us to assess the biasness of the estimator with different correlation values of $\rho$.

Figure 1 presents the estimation results for the simulated data when the true estimated value of $\gamma$ should be zero. The plot shows the simulated estimates of $\gamma$ are biased when correlation values of $\rho$ differ from zero. Stronger correlation between $\eta_{i}$ and $\varepsilon_{i}$ will lead to greater bias of $\gamma$. Increasing the sample size cannot eliminate the estimation bias. 


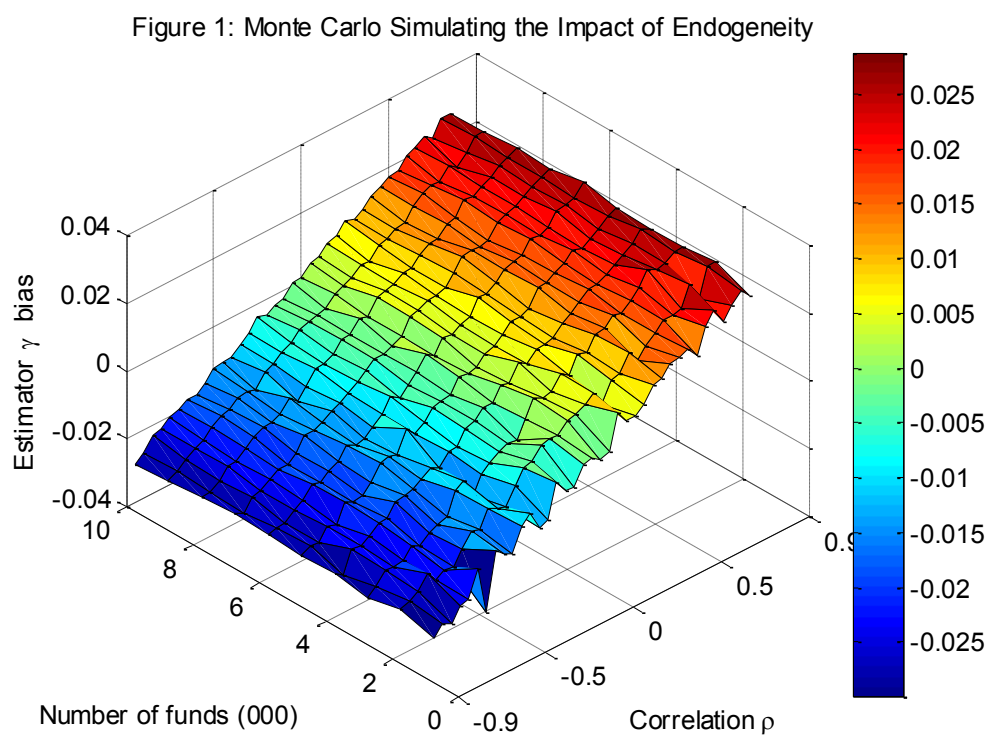


Table 1

Cross-sectional hedge fund characteristics.

\begin{tabular}{lcccccc}
\hline \hline & \multicolumn{3}{c}{ Live Funds } & \multicolumn{3}{c}{ Graveyard Funds } \\
\cline { 2 - 7 } Characteristics & Mean & Median & Std. & Mean & Median & Std. \\
\hline PC & 0.2277 & 0.0000 & 0.4194 & 0.2701 & 0.0000 & 0.4441 \\
PCA (M\$) & 21.3871 & 5.0000 & 34.3532 & 8.5466 & 2.0000 & 21.8651 \\
Management fee & 0.0143 & 0.0150 & 0.0058 & 0.0146 & 0.0150 & 0.0071 \\
Incentive fee & 0.1453 & 0.2000 & 0.0828 & 0.1565 & 0.2000 & 0.0767 \\
HWM & 0.6652 & 1.0000 & 0.4120 & 0.6148 & 1.0000 & 0.4866 \\
Leverage & 0.4929 & 0.0000 & 0.5000 & 0.5708 & 1.0000 & 0.4950 \\
Lock-up (month) & 3.1588 & 0.0000 & 6.7664 & 3.1278 & 0.0000 & 6.7468 \\
Pay-out (day) & 16.896 & 10.000 & 24.775 & 15.686 & 10.000 & 20.917 \\
RIA & 0.1692 & 0.0000 & 0.3750 & 0.0888 & 0.0000 & 0.2844 \\
Duration (year) & 8.6060 & 7.6712 & 5.7451 & 5.4926 & 4.4164 & 4.2220 \\
\hline
\end{tabular}

Note: This table presents the summary of cross-sectional hedge fund characteristics. Personal Capital $(P C)$ is a dummy variable that equals one if the fund manager has co-invested in the fund, and zero otherwise. Personal Capital Amount $(P C A)$ is a continuous variable measuring the dollar amount of hedge managers' co-investment. Management fee is proportional (typically between 1-2\%) to the total asset. Incentive fee is the term in the compensation contract which gives managers a percentage of any positive returns. It is reported as a percentage in the database. High-water-mark (HWM) is a dummy variable that equals one if the fund has a watermark provision and zero otherwise. Leverage is a dummy variable which equals one if the fund employs leverage and zero otherwise. Lock-up period refers to the time during which the invested money cannot be withdrawn. Pay-out period is the time period before investors will receive their capital back. RIA indicates whether the hedge fund has become registered with investment advisers. Duration is defined as the fund's time to failure. 
Table 2

Joint estimation results for multi-process Probit-hazard model using personal capital - full sample.

\begin{tabular}{|c|c|c|}
\hline \multirow[b]{2}{*}{ Variables } & \multicolumn{2}{|c|}{ Full Sample } \\
\hline & Coefficients & t-value \\
\hline \multicolumn{3}{|c|}{ Panel I: Probit Estimates } \\
\hline Constant & $-0.4915^{* * *}$ & -3.60 \\
\hline Management fee & $-6.4709^{* *}$ & -2.50 \\
\hline Incentive fee & $3.3120^{* * *}$ & 11.0 \\
\hline HWM & $-0.3060^{* * *}$ & -6.91 \\
\hline Leverage & $0.4604^{* * *}$ & 12.1 \\
\hline Lock-up period & $0.0612^{* * *}$ & 4.10 \\
\hline Pay-out period & $-0.1912^{* * *}$ & -7.48 \\
\hline RIA & $0.7598^{* * *}$ & 13.0 \\
\hline Category & $0.1799^{* * *}$ & 4.75 \\
\hline Initial AUM & $-0.3684^{* * *}$ & -4.91 \\
\hline \multicolumn{3}{|c|}{ Panel II: Hazard Estimates } \\
\hline Spline 0-5 & $0.4090^{* * *}$ & 13.1 \\
\hline Spline5-8 & 0.0000 & 0.00 \\
\hline Spline8+ & $0.0696^{* * *}$ & 6.32 \\
\hline Constant & $-0.4203^{* *}$ & -2.78 \\
\hline $\mathrm{PC}$ & 0.1535 & 0.86 \\
\hline Management fee & 2.6382 & 1.00 \\
\hline Incentive fee & $1.5608^{* * *}$ & 4.54 \\
\hline HWM & $0.1047 * *$ & 2.11 \\
\hline Leverage & -0.0526 & -1.15 \\
\hline Lock-up period & $0.0590^{* * *}$ & 3.26 \\
\hline RIA & $-0.4670^{* * *}$ & -6.14 \\
\hline Category & -0.0029 & -0.06 \\
\hline Fund return & $-1.0450^{* * *}$ & -26.6 \\
\hline Volatility & $0.7474^{* * *}$ & 24.5 \\
\hline AUM & $-0.4833^{* * *}$ & -15.0 \\
\hline \multicolumn{3}{|c|}{$0.4257^{* * *}$} \\
\hline$\sigma_{\mathcal{E}}$ & $1.0795^{* * *}$ & 9.77 \\
\hline$\rho$ & $-0.5848^{* * *}$ & -3.73 \\
\hline Log Likelihood & & \\
\hline
\end{tabular}

Note: This table reports the joint coefficient estimates of a Probit model for the fund manager's personal capital of Equation (1) and a log-continuous hazard model for the hedge fund failure of Equation (3). The dependent variable for Equation (1) takes on the value of one if the fund manager invests personal capital and zero otherwise. The sample extends from January 1994 to July 2014. The estimation results are obtained by full information maximum likelihood estimation. Figures marked with $* * *, * *$ and * are significant at the $1 \%, 5 \%$ and $10 \%$ levels respectively. 
Table 3

Effects of observed and unobserved managerial ownership attributes on fund survivorship risk - full sample.

\begin{tabular}{lcc}
\hline & & Full Sample \\
\cline { 2 - 3 } Variables & Coefficients & t-value \\
\hline Hazard Process & & \\
Spline0-5 & $0.3343^{* * *}$ & 17.7 \\
Spline5-8 & -0.0498 & -2.52 \\
Spline8+ & $0.0561^{* * *}$ & 6.76 \\
Constant & $-0.5683^{* * *}$ & -5.28 \\
$P C_{\text {unb }}$ & $-\mathbf{0 . 1 7 7 7 ^ { * * * }}$ & $\mathbf{- 5 . 3 6}$ \\
Management fee & -0.2262 & -0.11 \\
Incentive fee & $1.7292^{* * *}$ & 7.43 \\
HWM & 0.0970 & 2.73 \\
Leverage & -0.0038 & -0.12 \\
Lock-up period & $0.0515^{* *}$ & 3.55 \\
RIA & $-0.3547^{* * *}$ & -6.74 \\
Category & -0.0093 & -0.26 \\
Fund return & $-1.4197^{* * *}$ & -33.4 \\
Volatility & $0.3966^{* * *}$ & 14.1 \\
AUM & $-0.4082^{* * *}$ & -19.4 \\
$\sigma_{\varepsilon}$ & $0.7119^{* * *}$ & 9.41 \\
Log Likelihood & & \\
\hline
\end{tabular}

Note: This table reports the effects of observed and unobserved managerial ownership attributes on hedge fund failure. Both observed and unobserved attributes are generated by estimating the Probit model as shown below. The sample extends from January 1994 to July 2014. The estimation results are obtained by maximum likelihood estimation. Figures marked with $* * *, * *$ and $*$ are significant at the $1 \%, 5 \%$ and $10 \%$ levels respectively.

$$
\begin{aligned}
& \ln h_{i}(t)=\alpha+\tau T(t)++\delta_{1} P C_{u n b}+\beta X_{i}^{*}+\gamma Y_{i}(t)+\varepsilon_{i} \\
& \text { where } P C_{o b s}=\Phi\left(\hat{\lambda} X_{i}\right) \text { and } P C_{u n b}=P C_{i}-\Phi\left(\hat{\lambda} X_{i}\right)
\end{aligned}
$$


Table 4

Joint estimation results for multi-process OLS-hazard model using personal capital amount - full sample.

\begin{tabular}{|c|c|c|}
\hline \multirow[b]{2}{*}{ Variables } & \multicolumn{2}{|c|}{ Full Sample } \\
\hline & Coefficients & t-value \\
\hline \multicolumn{3}{|l|}{ Linear OLS Process } \\
\hline Constant & $6.6212^{* * *}$ & 19.7 \\
\hline Management fee & $0.2417^{* * *}$ & 3.16 \\
\hline Incentive fee & -0.0034 & -0.35 \\
\hline HWM & 0.0710 & 0.39 \\
\hline Leverage & -0.1274 & -1.11 \\
\hline Lock-up period & $0.2154^{* * *}$ & 6.76 \\
\hline Pay-out period & $0.2118^{* * *}$ & 8.87 \\
\hline RIA & $0.1761^{* *}$ & 1.89 \\
\hline Category & -0.1743 & -1.71 \\
\hline Initial AUM & $0.4161^{* * *}$ & 25.5 \\
\hline \multicolumn{3}{|l|}{ Hazard Process } \\
\hline Spline0-5 & $0.5036^{* * *}$ & 5.26 \\
\hline Spline5-8 & -0.0129 & -0.15 \\
\hline Spline8+ & 0.0294 & 0.84 \\
\hline Constant & $-1.1454^{*}$ & -1.53 \\
\hline PCA & 0.0393 & 0.58 \\
\hline Management fee & $23.9886^{*}$ & 1.88 \\
\hline Incentive fee & $3.1422^{* *}$ & 2.44 \\
\hline HWM & -0.2364 & -1.06 \\
\hline Leverage & -0.0934 & -0.64 \\
\hline Lock-up period & 0.0025 & 0.05 \\
\hline RIA & $-0.5579^{* * *}$ & -3.38 \\
\hline Category & -0.1841 & -1.30 \\
\hline Fund return & $-0.1461^{* * *}$ & -4.86 \\
\hline Volatility & $1.4979^{*}$ & 1.59 \\
\hline AUM & $-0.5082^{* * * *}$ & -4.81 \\
\hline$\sigma_{\eta}$ & $1.7340^{* * *}$ & 61.8 \\
\hline$\sigma_{\varepsilon}$ & $1.1833^{* * *}$ & 3.90 \\
\hline$\rho$ & $-0.4855^{* * *}$ & -3.80 \\
\hline Log Likelihood & & \\
\hline
\end{tabular}

Note: This table reports the joint coefficient estimates of a linear OLS model for fund managers' Personal Capital Amount (PCA) and a log-continuous hazard model for the hedge fund failure of Equation (3). The dependent variable for linear OLS regression is the actual amount that fund managers invest in the fund they run. The random error terms $\varepsilon$ and $\eta$ are assumed to follow a bivariate normal distribution with mean zero and variance-covariance matrix $\Omega$. The sample extends from January 1994 to July 2014. The estimation results are obtained by full information maximum likelihood estimation. Figures marked with $* * * * *$ and $*$ are significant at the $1 \%, 5 \%$ and $10 \%$ levels respectively.

$$
\begin{gathered}
\ln P C A_{i}=c+\lambda X_{i}+\eta_{i} \\
\ln h_{i}(t)=\alpha+\tau T(t)+\beta X_{i}^{*}+\gamma Y_{i}(t)+\delta\left(\ln P C A_{i}\right)+\varepsilon_{i}
\end{gathered}
$$


Table 5.a

Single process estimation results for hazard models using personal capital - full sample.

\begin{tabular}{|c|c|c|}
\hline \multirow[b]{2}{*}{ Variables } & \multicolumn{2}{|c|}{ Full Sample } \\
\hline & Coefficients & t-value \\
\hline \multicolumn{3}{|l|}{ Hazard Process } \\
\hline Spline0-5 & $0.3248^{* * *}$ & 17.5 \\
\hline Spline5-8 & $-0.0483^{* *}$ & -2.49 \\
\hline Spline8+ & $0.0561^{* * *}$ & 6.81 \\
\hline Constant & $-0.4543^{* * *}$ & -4.23 \\
\hline $\mathrm{PC}$ & $-0.2234^{* * *}$ & -6.21 \\
\hline Management fee & -0.5216 & -0.25 \\
\hline Incentive fee & $1.9140^{* * *}$ & 8.18 \\
\hline HWM & 0.0519 & 1.48 \\
\hline Leverage & 0.0248 & 0.76 \\
\hline Lock-up period & $0.0557^{* * * *}$ & 3.85 \\
\hline RIA & $-0.3257^{* * *}$ & -6.23 \\
\hline Category & 0.0082 & 0.23 \\
\hline Fund return & $-1.4415^{* * *}$ & -33.7 \\
\hline Volatility & $0.3621^{* * *}$ & 12.8 \\
\hline AUM & $-0.4138^{* * *}$ & -19.9 \\
\hline$\sigma_{\varepsilon}$ & $0.6988^{* * *}$ & 9.38 \\
\hline Log Likelihood & & \\
\hline
\end{tabular}

Note: This table reports the single coefficient estimates of a log-continuous hazard model for the hedge fund failure of Equation (3). The sample extends from January 1994 to July 2014. The estimation results are obtained by maximum likelihood estimation. Figures marked with $* * *, * *$ and $*$ are significant at the $1 \%, 5 \%$ and $10 \%$ levels respectively. 
Table 5.b

Single process estimation results for hazard models using cumulative incentive fees as managerial ownership - full sample.

\begin{tabular}{lcc}
\hline \hline & & Full Sample \\
Variables & Coefficients & t-value \\
\cline { 2 - 3 } Hazard Process & & \\
Spline0-5 & $0.4028^{* * *}$ & 25.1 \\
Spline5-8 & $-0.1238^{* * *}$ & -7.62 \\
Spline8+ & $0.0453^{* * *}$ & 7.05 \\
Constant & $-0.6065^{* * *}$ & -6.12 \\
Management fee & -1.4770 & -0.75 \\
Incentive fee & 0.0910 & 0.43 \\
HWM & $0.1065^{* * *}$ & 3.29 \\
Leverage & $-0.0825^{* *}$ & -2.73 \\
Lock-up period & $0.0721^{* * *}$ & 5.54 \\
RIA & $-0.3600^{* * *}$ & -7.30 \\
Category & -0.0001 & -0.00 \\
Fund return & $-1.2810^{* * *}$ & -43.1 \\
Volatility & 0.0206 & 0.39 \\
AUM & $-0.4127^{* * *}$ & -26.7 \\
Ownership & $\mathbf{1 . 7 4 9 4 * * *}$ & $\mathbf{5 0 . 0}$ \\
$\sigma_{\mathcal{E}}$ & $0.6070^{* * *}$ & 12.6 \\
Log Likelihood & & \\
\hline
\end{tabular}

Note: This table reports the single coefficient estimates of a log-continuous hazard model for the hedge fund failure of Equation (3) except for PC being replaced by incentive fees reinvestment (Ownership). The sample extends from January 1994 to July 2014. The estimation results are obtained by maximum likelihood estimation. Figures marked with $* * *, * *$ and $*$ are significant at the $1 \%, 5 \%$ and $10 \%$ levels respectively. 
Table 6

Joint estimation results for multi-process Probit-hazard model using personal capital - absolute defunct sample.

\begin{tabular}{|c|c|c|}
\hline \multirow[b]{2}{*}{ Variables } & \multicolumn{2}{|c|}{ Absolute Defunct Sample } \\
\hline & Coefficients & t-value \\
\hline \multicolumn{3}{|l|}{ Probit Process } \\
\hline Constant & $-0.9675^{* * *}$ & -4.97 \\
\hline Management fee & $-7.2771^{* *}$ & -2.03 \\
\hline Incentive fee & $3.5260^{* * * *}$ & 8.56 \\
\hline HMW & $-0.2027^{* * *}$ & -3.52 \\
\hline Leverage & $0.6128^{* * *}$ & 12.0 \\
\hline Lock-up period & $0.0400^{*}$ & 1.88 \\
\hline Pay-out period & $-0.0858^{* * * *}$ & -5.25 \\
\hline RIA & $0.9045^{* * *}$ & 11.2 \\
\hline Category & $0.1974^{* * *}$ & 3.80 \\
\hline Initial AUM & $-0.0261^{* *}$ & -2.50 \\
\hline \multicolumn{3}{|l|}{ Hazard Process } \\
\hline Spline 0-5 & $0.3267^{* * * *}$ & 14.0 \\
\hline Spline5-8 & $-0.0758^{* * *}$ & -2.89 \\
\hline Spline8+ & 0.0116 & 1.03 \\
\hline Constant & 0.1894 & 1.21 \\
\hline $\mathrm{PC}$ & 0.0481 & 0.33 \\
\hline Management fee & 2.5974 & 0.75 \\
\hline Incentive fee & $2.3556^{* * *}$ & 6.57 \\
\hline HMW & $-0.1443^{*}$ & -2.74 \\
\hline Leverage & -0.0271 & -0.50 \\
\hline Lock-up period & -0.0111 & -0.48 \\
\hline RIA & $-0.4753^{* * *}$ & -5.19 \\
\hline Category & 0.0473 & 0.81 \\
\hline Fund return & $-2.0174^{* * *}$ & -21.4 \\
\hline Volatility & 0.0507 & 0.93 \\
\hline AUM & $-0.5368^{* * * *}$ & -18.5 \\
\hline$\sigma_{\eta}$ & $0.4540^{* * * *}$ & 3.06 \\
\hline$\sigma_{\varepsilon}$ & $0.8348^{* * *}$ & 9.41 \\
\hline$\rho$ & $-0.4327^{* *}$ & -2.61 \\
\hline Log Likelihood & & \\
\hline
\end{tabular}

Note: This table reports the joint coefficient estimates of a Probit model for the fund manager's personal capital of Equation (1) and a log-continuous hazard model for the hedge fund failure of Equation (3) using the Absolute Defunct sample which includes only the "liquidation" category as Defunct funds. The dependent variable for Equation (1) takes on the value of one if the fund manager invests personal capital and zero otherwise. The sample extends from January 1994 to July 2014. The estimation results are obtained by full information maximum likelihood estimation. Figures marked with $* * *, * *$ and $*$ are significant at the $1 \%, 5 \%$ and $10 \%$ levels respectively. 